\title{
Sickle cell exerted protection against malarial infection in Nigerian children (6-59 months)
}

Malaria, caused by five Plasmodium species, is responsible for morbidity and mortality in many countries. ${ }^{1}$ Globally, approximately 228 million cases of malaria were reported by the World Health Organization in 2018, and Nigeria is the country with the greatest number of cases (25\%). ${ }^{2}$ These cases of malaria resulted in an estimated 405,000 deaths with children aged 6-59 months, accounting for $67 \%$ of the total global malarial deaths. ${ }^{2}$

Sickle cell disease, a genetic disorder caused by the mutation of the beta-globin gene, results in the formation of abnormal hemoglobin, is now a worldwide concern. In West African countries, most mutations are found in S or C types of hemoglobin. ${ }^{3}$ The homozygote genotype (SS or $\mathrm{CC}$ ) is responsible for sickle cell anemia, whereas the heterozygote genotype AS or AC induces mild disease referred to as the sickle cell trait. ${ }^{3}$ Around $5 \%$ of the worldwide population carries abnormal genes in hemoglobin, with around 300,000 children born each year carrying abnormal genotypes. ${ }^{4}$ Though, various studies suggest that genotypes have a relationship with the occurrence of malaria, which one of these genotypes is associated with the protection against malaria remains unclear. $^{1,3-9}$ In this study, the association of the sickle cell genotypes with the occurrence of malaria in Nigerian children is examined.

In the Nigerian Demographic Health Survey 2018, genotypes (AA, AC, AS, SC, SS, and others) were tested for the first time to determine sickle cell disease. ${ }^{10}$ In this study, we selected 7409 children aged 6-59 months who has been tested for both malaria and their genotype. The frequency distribution and odds ratio were calculated using STATA software (version 16.0). We used four models to figure out the exact relationship between the $\mathrm{S}$ or $\mathrm{C}$ alleles with the malaria occurrence in Nigerian children (Table 1). Among all children, 2851 (38.48\%) tested positive for malaria. In the case of normal (AA) genotype, among the study population, $38.60 \%$ of children were reported as malaria positive (Table 1).

From model 1, the odds of the malaria occurrence were $52.3 \%$ lower in the SS genotype (OR $0.477 ; 95 \%$ CI $0.267-0.852 ; p=0.012$ ) compared to the AA genotype (Table 1), indicating an association between the SS genotype and reduced malarial infection. In our study, we observed a non-significant relationship between the malaria occurrence and AS genotype (OR 0.978; 95\% CI 0.868-1.102; $p=0.713$ ), in contrast to previous studies where both the SS and AS genotypes were found to protect against malaria infection. ${ }^{5,6}$ This may be due to the higher humoral Plasmodium falciparum immunoglobulin (IgG) response in children with sickle cell genotype (SS) than normal genotype (AA). ${ }^{1}$ It assumes that the macrophage can destroy parasitized erythrocytes, thus impair cytoadherence of defective erythrocytes to microvascular endothelial cells, which may result in malaria protection in a sickle cell carrying individual. ${ }^{1}$ Other traits such as hemoglobin $\mathrm{C}$ trait (AC) and HB C diseases (SC) exerted a non-significant relation with malaria occurrence ( $p=0.13$, and 0.63 , respectively). Though Gouagna et al., reported a significantly higher occurrence of malaria in the case of AC genotypic individuals compared to the AA genotypic individuals in Burkina Faso. ${ }^{7}$ In addition, Gonçalves et al. reported that individuals having heterozygous genotype AC were associated with higher falciparum infections while sickle cell traits AS had a lower infection risk compared to AA genotypes. ${ }^{8}$ Furthermore, a contradictory report is present by Modiano et al. that hemoglobin C containing genes (AC, SC) were protective against malaria parasites. ${ }^{9}$ From the model 2, model 3, and model 4 it appears that the association of $\mathrm{S}$ or $\mathrm{C}$ alleles with malaria occurrence were not significant (Table 1).

We found that malaria occurrence was lower only in the case of sickle cell anemia (SS) gene carrying children of Nigeria. On the other hand, the sickle cell trait (AS), HB C trait (AC), HB C diseases (SC), and other genes did not exert any protection against malarial infection. Based on our knowledge, this is the first examination of the association between malaria and sickle cell disease using country representative data from Demographic Health Survey. ${ }^{10}$ This study adds to the literature

Table 1

Distribution of malarial infection and the effects of genotype on the occurrence of malaria using logistic regression, children aged 6-59 months, Nigeria 2018 $(\mathrm{N}=7409)$.

\begin{tabular}{|c|c|c|c|}
\hline Genotype & $\begin{array}{l}\text { Malaria negative } \mathrm{n} \\
(\%)\end{array}$ & Malaria positive $\mathrm{n}(\%)$ & \\
\hline Normal (AA) & $3550(61.40)$ & $2232(38.60)$ & \\
\hline Sickle cell trait (AS) & 880 (61.93) & 541 (38.07) & \\
\hline HB C trait (AC) & $61(54.46)$ & $51(45.54)$ & \\
\hline HB C diseases (SC) & $13(56.52)$ & $10(43.48)$ & \\
\hline $\begin{array}{l}\text { Sickle cell anemia } \\
\text { (SS) }\end{array}$ & $50(76.92)$ & $15(23.08)$ & \\
\hline Others & $4(66.67)$ & $2(33.33)$ & \\
\hline \multirow[t]{2}{*}{ Total } & $4558(61.52)$ & $2851(38.48)$ & \\
\hline & Genotype & $\begin{array}{l}\text { Odds ratio (OR) (95\% } \\
\mathrm{CI})\end{array}$ & $p$ value \\
\hline \multirow[t]{7}{*}{ Model-1 $(\mathrm{N}=7409)$} & Ref. $(A A)$ & - & - \\
\hline & $A S$ & $0.978(0.868-1.102)$ & 0.713 \\
\hline & $A C$ & $1.330(0.913-1.936)$ & 0.137 \\
\hline & $S C$ & $1.223(0.536-2.795)$ & 0.632 \\
\hline & SS & $0.477(0.267-0.852)$ & 0.012 \\
\hline & Others & $0.795(0.145-4.345)$ & 0.791 \\
\hline & Constant & $0.629(0.596-0.663)$ & $<0.001$ \\
\hline \multirow[t]{3}{*}{ Model-2 $(\mathrm{N}=7403)$} & Ref. (AA) & - & - \\
\hline & $(A S+S S+A C+S C)$ & $0.977(0.873-1.095)$ & 0.693 \\
\hline & Constant & $0.629(0.596-0.663)$ & $<0.001$ \\
\hline \multirow[t]{3}{*}{ Model-3 $(\mathrm{N}=7268)$} & Ref. (AA) & - & - \\
\hline & $A S+S S$ & $0.951(0.845-1.070)$ & 0.401 \\
\hline & Constant & $0.629(0.596-0.663)$ & $<0.001$ \\
\hline \multirow[t]{3}{*}{ Model-4 $(\mathrm{N}=5917)$} & Ref. (AA) & - & - \\
\hline & $A C+S C$ & $1.311(0.930-1.848)$ & 0.122 \\
\hline & Constant & $0.629(0.596-0.663)$ & $<0.001$ \\
\hline
\end{tabular}


examining the relationship between sickle cell diseases and malaria.

\section{Funding}

The 2018 Nigeria Demographic and Health Survey (2018 NDHS) was conducted by the National Population Commission (NPC) in cooperation with the National Malaria Elimination Programme (NMEP) of the Federal Ministry of Health, Nigeria. The funding for the 2018 NDHS was provided by the United States Agency for International Development (USAID), Global Fund, Bill and Melinda Gates Foundation (BMGF), the United Nations Population Fund (UNFPA), and World Health Organization (WHO).

\section{Contributors}

GMRI design the editorial, JHS analyze the data and draft editorial, GMRI careful review the current literature and revised the editorial.

\section{Declaration of competing interest}

The authors have no conflicts of interest.

\section{Acknowledgments}

Authors are thankful the DHS to permit to conduct this study. Research reported in this publication was supported by the Fogarty International Center and National Institute of Mental Health, of the National Institutes of Health under Award Number D43 TW010543. The content is solely the responsibility of the authors and does not necessarily represent the official views of the National Institutes of Health.

\section{References}

1. Bwire GM, Majigo M, Makalla R, et al. Immunoglobulin G responses against falciparum malaria specific antigens are higher in children with homozygous sickle cell trait than those with normal hemoglobin. BMC Immunol. 2019;20(1):1-8. https:// doi.org/10.1186/s12865-019-0294-Z.
2. World Health Organization. World malaria report 2019. World health organization. https://apps.who.int/iris/handle/10665/330011; 2019. License: CC BY-NC-SA 3.0 IGO.

3. Tossea SK, Adji EG, Coulibaly B, et al. Cross sectional study on prevalence of sickle cell alleles $\mathrm{S}$ and $\mathrm{C}$ among patients with mild malaria in Ivory Coast. BMC Res Notes. 2018;11(1):1-7. https://doi.org/10.1186/s13104-018-3296-7.

4. Gong L, Parikh S, Rosenthal PJ. Biochemical and immunological mechanisms by which sickle cell trait protects against malaria. Mal j. 2013;12(1):1-9. https://doi. org /10.1186/1475-2875-12-317.

5. Uyoga S, Macharia AW, Ndila CM, et al. The indirect health effects of malaria estimated from health advantages of the sickle cell trait. Nat Commun. 2019;10(1): 856. https://doi.org/10.1038/s41467-019-08775-0.

6. Williams TN, Obaro SK. Sickle cell disease and malaria morbidity: a tale with two tails. Trends Parasitol. 2011;27(7):315-320. https://doi.org/10.1016/j. pt.2011.02.004.

7. Gouagna LC, Bancone G, Yao F, et al. Genetic variation in human HBB is associated with Plasmodium falciparum transmission. Nat Genet. 2010;42(4):328-331. https:// doi.org/10.1038/ng.554.

8. Gonçalves BP, Sagara I, Coulibaly M, et al. Hemoglobin variants shape the distribution of malaria parasites in human populations and their transmission potential. Sci Rep. 2017;7(1):14267. https://doi.org/10.1038/s41598-017-14627-y.

9. Modiano D, Luoni G, Sirima BS, et al. Haemoglobin C protects against clinical Plasmodium falciparum malaria. Nature. 2001;414(6861):305-308. https://doi.org/ 10.1038/35104556.

10. National Population Commission (NPC). ICF. Nigeria demographic and health Survey 2018 [Internet]. In: Abuja, Nigeria, and Rockville, Maryland, USA: NPC and ICF. 2019:707. Report No.: 6. Available from: dhsprogram.com.

Jahid Hasan Shourove Shahjalal University of Science and Technology, Food Engineering and Tea Technology, Sylhet, Bangladesh

G.M. Rabiul Islam*

Shahjalal University of Science and Technology, Food Engineering and Tea Technology, Sylhet, Bangladesh

Harvard T.H. Chan School of Public Health, Harvard University, USA

* Corresponding author. Shahjalal University of Science and Technology, Food Engineering and Tea Technology, Sylhet, Bangladesh. E-mail address: rabi-ttc@sust.edu (G.M.R. Islam). 